\title{
Histone Deacetylase Inhibitors and Anaplastic Thyroid Carcinoma
}

\author{
ELEFTHERIOS SPARTALIS ${ }^{1^{*}}$, DIMITRIOS I. ATHANASIADIS ${ }^{2 *}$, DIMOSTHENIS CHRYSIKOS ${ }^{3}$, \\ MICHAEL SPARTALIS ${ }^{1}$, GEORGIOS BOUTZIOS ${ }^{4}$, DIMITRIOS SCHIZAS ${ }^{5}$, NIKOLAOS GARMPIS ${ }^{6}$, \\ CHRISTOS DAMASKOS ${ }^{6}$, STAVROULA A. PASCHOU ${ }^{1}$, ARGYRIOS IOANNIDIS ${ }^{1}$, \\ GERASIMOS TSOUROUFLIS ${ }^{6}$, DIMITRIOS DIMITROULIS ${ }^{6}$ and NIKOLAOS I. NIKITEAS ${ }^{1,6}$ \\ ${ }^{1}$ Laboratory of Experimental Surgery and Surgical Research N.S. Christeas, Medical School, \\ National and Kapodistrian University of Athens, Athens, Greece; \\ ${ }^{2} 1$ st Department of Surgery, "Papageorgiou" General Hospital, Medical School, \\ Aristotle University of Thessaloniki, Thessaloniki, Greece; \\ ${ }^{3}$ University Department of Surgery, General and Oncologic Hospital of Kifissia 'Agii Anargiri', Athens, Greece; \\ ${ }^{4}$ Endocrine Unit, Department of Pathophysiology, Medical School, \\ National and Kapodistrian University of Athens, Athens, Greece; \\ ${ }^{5} 1$ st Department of Surgery, Medical School, National and Kapodistrian University of Athens, Athens, Greece; \\ ${ }^{6}$ 2nd Department of Propaedeutic Surgery, Medical School, \\ National and Kapodistrian University of Athens Athens, Greece; \\ ${ }^{7}$ Division of Endocrinology and Diabetes, "Aghia Sophia" Hospital, Medical School, \\ National and Kapodistrian University of Athens, Athens, Greece
}

\begin{abstract}
Background/Aim: Anaplastic thyroid cancer (ATC) is one of the most aggressive human malignancies, remaining generally incurable. Histone deacetylase (HDAC) seems to play a role in regulating transcription of genes involved in ATC, making HDAC inhibitors (HDACI) promising anticancer drugs for ATC. The purpose of this review was to evaluate the role of HDACIs in ATC treatment and describe the latest trends of current research on this field. Materials and Methods: This literature review was performed using the MEDLINE database. The keywords/phrases were; thyroid cancer, anaplastic, HDAC, histone, deacetylase*, HDACI. Results: Compounds, such as SuberoylAnilide Hydroxamic Acid, valproic acid, sodium butyrate, butyrate, phenylbutyrate,
\end{abstract}

This article is freely accessible online.

*These Authors contributed equally to this study.

Correspondence to: Eleftherios D. Spartalis MD, MSc, Ph.D., FACS, 49 Vasilissis Sofias Ave. Athens, 10676, Greece. Tel: +30 6974714078, e-mail: eleftherios.spartalis@gmail.com

Key Words: HDAC, histone deacetylase inhibitors, anaplastic, thyroid, cancer, review. trichostatin A, AB1-13, panobinostat or LBH589, belinostat, MS-275, depsipeptide, CUDC101, CUDC907, N-Hydroxy-7-(2naphthylthio)-Hepanomide (HNHA), and PXD101 have shown promising antitumor effects against ATC. Conclusion: HDACIs represent a promising therapy for ATC management, both as monotherapy and in combination with other anticancer drugs.

Anaplastic thyroid carcinoma (ATC), is one of the most aggressive human malignancies. It is an undifferentiated thyroid cancer responsible for most thyroid cancer deaths, with an overall survival rate as low as $13 \%$, despite accounting for only about $1 \%$ of the thyroid cancer incidence (1-4). Furthermore, early tumor dissemination results in $20-50 \%$ of patients having distant metastases and in $90 \%$ having adjacent tissue invasion on presentation (5). Thus, most often patients present with mass effects that cause compressive symptoms, without hormone-related symptoms (6).

ATC is refractory to current conventional treatments with radioiodine ablation and chemotherapy, while radiation therapy with thyroidectomy is being considered only for airway decompression (6). The median survival from diagnosis ranges from 3 to 7 months and the one- and five-year survival rates are $20-35 \%$ and $5-14 \%$, respectively (7-11). Therefore, due to its oncological behavior, there is an urgent need for novel, more innovative immunological and gene therapies (12). 
Histone deacetylase inhibitors (HDACIs) are a promising class of drugs in thyroid cancer. Histone deacetylases (HDACs) are enzymes that remove the acetyl groups, a process called deacetylation, from histone lysine residues. The process of deacetylation creates more positive charges on the histones and thus increases the interaction of the positively charged $\mathrm{N}$ termini of histones with the negatively charged phosphate groups of DNA. These interactions transform DNA into a more condensed form, making it less accessible to the cell's transcriptional machinery $(13,14)$. Deacetylation-mediated inhibition of tumor suppressor genes leads to the progression of tumors (15).

There are many types of HDACs, mainly divided into four classes: (a) class I includes HDACs 1, 2, 3 and 8; (b) class II includes HDACs 4, 5, 6, 7, 9 and 10; (c) class III HDACs are the sirtuins (SIRT1-7); and (d) class IV contains HDAC $11(16,17)$. Different HDAC subtypes are considered to be associated with different cancer characteristics and behaviors like HDAC-1, -4, -6 being closely related to tumor size; HDAC-4 is also related to capsular invasion, and HDAC-2 is considered to play a role in lymphatic and vascular invasion of malignant neoplasms (18).

HDACIs have been extensively studied as potential drugs for treating cancer with vorinostat (SuberoylAnilide Hydroxamic Acid) being the first to receive approval for clinical use in cutaneous T-cell lymphoma (19). One of the first well-studied HDACIs for treating thyroid malignancies is suberoylanilide hydroxamic acid (SAHA), which has been already approved by the FDA for the treatment of several neoplastic diseases $(20,21)$ and has antitumor activities against thyroid cancer (22).

HDACIs can induce tumor growth arrest, differentiation, and apoptosis (23). Moreover, they can sensitize tumor cells to radiation, increase radioiodine uptake and intratumoral radioiodine accumulation, organification, and chemotherapy (24). However, the most crucial role of these drugs is the deacetylation of the $\mathrm{NH} 2$ terminal of lysine residues leading to the change of DNA configuration regulating gene expression (25).

In vitro and in vivo studies have shown their effectiveness against human thyroid cancer cell lines. Even though there is only one report of a randomized multicenter phase II/III clinical trial testing the effect of HDACIs in patients with ATC (26), more than 50 articles describing the effects of HDACIs in cell lines have shown promising results. These drugs are being tested either alone or in combination with other cytotoxic or targeted cancer treatments on human thyroid cell lines in vitro. The cell lines that were mostly used are ARO cells, ARO81-1, FRO, DR090-1, CAL-62, 8305C, GSA1 and 2, BHT-101, SW1736, and C643. Each cell line has unique features, expresses different genes and has a different response to each medication. Furthermore, some studies presented results from cell lines which derived from human cancer biopsies and expressed a unique set of different genes. The main characteristics of the different cell lines are summarized in Table I.

Some data suggest that single-agent HDACIs may not be a viable treatment when used alone for ATC (27). As such, a number of studies suggest the usage of two or more HDACIs or the combination of HDACIs with tyrosine kinase inhibitors (TKI) in order to maximize the therapeutic effect (28). This review discusses all the main compounds used for the treatment of ATC, their mechanism of action and their effect on tumor progression. These include: SuberoylAnilide Hydroxamic Acid, valproic acid, sodium butyrate, butyrate, phenylbutyrate, trichostatin $\mathrm{A}, \mathrm{AB} 1-13$, panobinostat or LBH589, belinostat, MS-275, depsipeptide, CUDC101, CUDC907, N-Hydroxy-7-(2-naphthylthio)-Hepanomide (HNHA), and PXD101. The major mechanisms of action of these agents are summarized in Table II.

\section{SuberoylAnilide Hydroxamic Acid}

SuberoylAnilide Hydroxamic Acid (SAHA) or Vorinostat is a hydroxamic acid and anilide derivative that acts as an HDACI of class I and II HDACs. It has antineoplastic activity on many cancer cells including anaplastic thyroid cancer cells. Treatment of these cancer cells with $5 \mu \mathrm{M}$ of SAHA for $30 \mathrm{~min}$ induced histone acetylation, leading to increased expression of $\mathrm{Na} / \mathrm{I}$ symporter (NIS), thyroid stimulating hormone receptor (TSHR), thyroid peroxidase (TPO) and thyroglobulin $(\mathrm{Tg})(29,30)$. Their effect on SW1736, Hth7 and C643 thyroid cells was increased when they were combined with RDEA119, a MEK inhibitor, temsirolimus, an mTOR inhibitor, and perifosine, an AKT inhibitor. With the addition of TSH, there was an up-regulation of NIS, TSHR, TPO, Tg, PAX8, FOXE1, and TTF1. In addition, the combination of SAHA, perifosine and TSH increased the sensitivity of iodide uptake (29). Furthermore, SAHA downregulated HuR via decreasing NF-kB on SW1736 cells (31).

On the other hand, when ATC 8505C cells were treated with $10 \mathrm{nM}$ SAHA for $48 \mathrm{~h}$, the concentration of NIS remained stable, but when used on C643, there was a strong re-expression of NIS. Interestingly, when the cell line's basal NIS concentration was low, like in C643 cell line, SAHA caused re-expression of NIS leading to increased protein levels. However, when the NIS concentration was not low from the beginning, the concentration remained stable after the treatment. The same effect was observed when the cell lines were treated with Trichostatin A and Panobinostat (32).

Its anti-proliferative effects and the up-regulation of TSHR mRNA were potentiated by the PARP inhibitor PJ34 (33). However, when used in combination with 1,25dihydroxy vitamin D3, this additive effect was only observed in Hth74 and C643 cell lines and ranged from 25\% to $35 \%$ inhibition of growth (34). In FRO cells, SAHA induced 
Table I. Anaplastic thyroid cancer (ATC) human cell lines mainly used in the in vitro experiments.

\begin{tabular}{ll}
\hline Cell line & Main characteristics \\
\hline ARO & Homoz (-)TP53, SMAD4, Heteroz APC, BRAF, PIK3CA, EGFR \\
ARO81-1 & Heterozygous BRAF, Val600Glu, TP53, APC, PIK3CA \\
FRO & Homozygous $(-) T P 53$ \\
DR090-1 & $(+)$ for Somatostatin receptors \\
CAL-62 & KRAS(G12R) mutation \\
SW1736 & TERT promoter mutation leading to increased BRAF(V600E)/RAS \\
$8505 C$ & Mutation at $T P 53$ gene and BRAF(V600E) \\
GSA1,2 & $(+) F G F R, V E G F, C D K 3$, MEK2, $(-) T P 53$ \\
C643 & Abnormal MAPK pathway, including RET/PTC, Ras and BRAF mutations \\
BHT-101 & $B R A F(V 600 \mathrm{E})$, heterozygous for TERT \\
SNU-80 & Mutations in $T P 53$, BRAF(V600E) \\
C643 & $T P 53$ and HRAS mutations
\end{tabular}

Table II. The main mode of action of Histone deacetylase inhibitors (HDACIs) in anaplastic thyroid cancer (ATC).

\begin{tabular}{ll}
\hline Substance & Action \\
\hline SAHA & Cell apoptosis and regression of tumor growth \\
VPA & Cell cycle arrest at $\mathrm{G}_{1}$ phase, inhibition of proliferation \\
Butyrate & Reduction in cell growth and cell cycle arrest \\
Sodium Butyrate & Dose-dependent inhibition of cell proliferation, induction of apoptosis \\
Phenylbutyrate & Potent cytotoxic activity \\
SuberoylAnilide Hydroxamic Acid & Regression of tumor growth \\
AB2,3,10 & Induction of apoptosis and re-sensitization of cells to radioiodine ablation \\
Panobinostat & Reversion of radioiodine resistance and decrease in cell viability \\
Belinostat & Dose-dependent inhibition of cell proliferation, apoptosis \\
MS-275 & Inhibition of cell apoptosis \\
Depsipeptide & Reversion of sensitivity to radioiodine ablation \\
CUDC101 & Inhibition of cell growth and cycle arrest at $\mathrm{G}_{2} / \mathrm{M}$ \\
CUDC907 & Decrease in cell proliferation, arrest at $\mathrm{G}_{2} / \mathrm{M}^{2}$ cell cycle phase and increase apoptosis \\
HNHA & Dose-dependent reduction of viability of cells and apoptosis \\
Triptolide & Increased cytotoxicity and apoptosis \\
\hline
\end{tabular}

apoptosis via inhibiting degradation and thus increasing TRAIL protein levels (same mRNA levels), especially when combined with the MS-275 HDACI (35).

Also, SAHA caused cell death by suppressing PI3K/Akt/ mTOR, inactivating survivin, an anti-apoptotic protein, and activating of DNA damage-related proteins via decreasing acetylation of $\mathrm{H} 3, \mathrm{H} 4$. When used in combination with SNX5422, a heat shock protein 90 inhibitor, these effects were potentiated (36).

\section{Valproic Acid}

Valproic acid (VPA) is a branched fatty acid that is commonly used for its anticonvulsant activity in seizures, epilepsy. However, a new indication for VPA as an HDACI was discovered, specifically for the treatment of malignancies including thyroid neoplasms. In vitro studies have shown that
VPA increases expression of NIS in ARO cells (37) and Ecadherin expression on BHT101, and 8350C cells (38). On the other hand, studies on $8505 \mathrm{C}$ cells have shown that VPA and Sodium Butyrate, another HDACI, increase the sensitivity of ATC cells to radiation via impairing DNA damage repair processes, apart from increasing NIS concentration (39). Moreover, it increases p21 mRNA and induces $\mathrm{G}_{1}$ cell-cycle arrest only when used in combination with imatinib in ARO cells. When used alone, neither VPA nor imatinib induced a similar effect (40). The combined action of VPA and doxorubicin on ARO and Cal-62 cells caused increased cytotoxicity, halting apoptosis and increasing accessibility of DNA. Their combination also resulted in $\mathrm{G}_{2}$ arrest and reduced production of free radicals, suggesting fewer complications due to doxorubicin toxicity (41).

However, in contrast to in vitro human cell studies, in a phase II/III clinical trial of the combination of VPA with 
paclitaxel (TAX) in patients with anaplastic thyroid cancer along, there was no benefit in the final outcome nor in TAX's pharmacokinetics (26).

\section{Trichostatin A}

Trichostatin A (TSA), is a commonly used antifungal drug that can also inhibit HDACs and, therefore can be used in the treatment of different malignancies. Furthermore, TSA sensitized SW579 cells to radiation with iodide but to a lesser extent than silencing HDACs with shRNA (short-heparin RNA) (42). When combined with SNX5422, they synergistically suppressed PI3K/Akt/mTOR and survivin, and activated DNA damage-related proteins (36). When used along with sodium butyrate, another HDACI, they increased NIS expression in FRO, ARO, and SW1736 cell lines and expression of PAX8 only in ATC ARO cells (43). Furthermore, the combination of TSA $(300 \mathrm{nM})$ with sodium butyrate $(3 \mathrm{mM})$ suppressed HDAC- 1 and 2 and increased mRNA alternative splicing of prohibitin (PHB), a ubiquitous protein, in FRO thyroid cells. The PHB transcript is normally spliced into two isoforms, the 3'UTR and PHB SHORT. However, the treatment combination of TSA and sodium butyrate induced a specific increase in the 3'UTR isoform through alternative splicing. 3'UTR's action, though, encodes for another isoform that contains an untranslated sequence that eventually induces a proliferation blockage (44). TSA induced tumor suppression and this effect was independent of p53. Also, it increased apoptosis by caspases activation and a decrease in cyclin A, B levels and also increased the levels of cyclin-dependent kinases inhibitors p21, p27. These effects result in cell cycle arrest at the $G_{1}$ phase in DR090-1 cells along with a pRb hypophosphorylation and cell cycle arrest at the $\mathrm{G}_{2}$ phase in ARO81-1 cells (45).

Moreover, TSA increased the levels of Rap1GAP and RAP2, regulators of HDAC expression (46), and modulated Ecadherin expression on BHT101, CAL62 and 8305C cells (38).

\section{N-Hydroxy-7-(2-naphthylthio)-Hepanomide}

N-hydroxy-7-(2-naphthylthio)-Hepanomide (HNHA) is a potent HDACI and is being tested in many different cancer types including breast cancer, renal cell carcinoma, medulloblastoma, and anaplastic thyroid cancer. Specifically, on anaplastic thyroid cancer cells. It inhibited progression to $\mathrm{G}_{0} / \mathrm{G}_{1}$ phase leading to cell-cycle arrest, reduction of Bcl-2 and Ki-67 and apoptosis. Moreover, along with lenvatinib, an FGFR inhibitor, and sorafenib, a tyrosine kinases inhibitor, HNHA was more toxic and decreased proliferation of GSA1, GSA2 cells. The combination with lenvatinib resulted in inhibition of the FGFR pathway, a decrease in PKC, MEK, p-ERK1/2, MET and a dramatical increas in E-cadherin more than HNHA alone or in combination with sorafenib (47). HNHA induced an endoplasmic reticulum stress-dependent cell cycle arrest, an increase in p53 and p21, and a decrease in cyclin D1, CDK4 and CDK6 levels in 8505X, SNU80 and GSA1 anaplastic thyroid cells. When combined with sorafenib, cell viability was further decreased and cells arrested at $\mathrm{G}_{0} / \mathrm{G}_{1}$ phase, Apaf-1, NF$\mathrm{kB}, \mathrm{p} 65$, and $\mathrm{Bcl}-2$ levels increased, and apoptosis was induced through the cleavage of caspase-3 (48). HNHA induced acetylation of $\mathrm{H} 3$ and compared to TSA and SAHA, it led to a more significant reduction in cell proliferation along with increased cytotoxicity. Finally, HNHA induced a higher increase in the levels of cytoplasmic calcium than the other drugs and led to a stronger induction of apoptosis (49).

\section{Butyrate}

Butyrate is a short-chain fatty acid that competitively binds to the zinc sites of class I and II HDACs inducing cell cycle arrest in $G_{1}$ or $G_{2} / M$ phase. Specifically, in anaplastic thyroid cancer decreased the levels of cyclin A and B, and by increasing cyclin-dependent kinase inhibitors p21 and p27 induced cell cycle arrest at $\mathrm{G}_{1}$ phase in both DR090-1 and ARO81-1 cells. Furthermore, butyrate induced caspasedependent apoptosis independently of p53 (45).

Sodium butyrate $(\mathrm{NaB})$, the most commonly used, increases Rap1GAP protein levels which are commonly low in cancers. It also decreased the expression of RAP2 via inhibiting regulators like RapGEFs and RapGAPs in Hth7, Hth74, Hth83, Hth104, Hth112 and SW1736 cells (46). In combination with TSA, they increased NIS expression in FRO, ARO, and SW1736 cells and expression of PAX8 only in ARO cells (43).

The combination of phenylbutyrate (Phb), another butyrate analogue, with COX inhibitors and cisplatin derivatives resulted in higher levels of cytotoxicity compared to both cisplatin and oxaliplatin. They were 51 times more selective for thyroid cells than cisplatin. The use of VPA instead of Phb led to the same results with the exception that the VPA effects were not exerted through HDAC inhibition (50).

\section{CUDC101}

CUDC-101 is a novel inhibitor of class I HDACs. The combination of CUDC-101 and carfilzomib resulted in higher inhibition of cell growth and proteasome in $8505 \mathrm{C}$, SW1736, C643 anaplastic thyroid cells compared to treatment with each one separately. Specifically, in 8505C and C-643 the two medications synergistically induced cell cycle arrest at $\mathrm{G}_{2} / \mathrm{M}$. What is more, they dramatically increased expression of p21 and PARP, an apoptotic marker cleaved by caspase 3 (51).

\section{CUDC907}

CUDC907 is both a tyrosine kinase inhibitor and an HDACI. It increases the acetylation of $\mathrm{H} 3$ and decreases HAC2 
protein levels. In $8505 \mathrm{C}$ thyroid anaplastic cancer cells, it decreased cell migration and invasion by decreasing the expression of TWIST-1 protein levels, which normally repress E-cadherin's expression. Moreover, it induced cell cycle arrest at $\mathrm{G}_{2} / \mathrm{M}$ via increasing $\mathrm{p} 21$ expression and reducing expression of cyclin B1, AURKA, B, and PLK1. Furthermore, CUDC907 increased the apoptotic rate by inducing caspase $3 / 7$ activity and increasing p27 and survivin protein levels by increasing caspases 3 and 9 activity. In addition, it decreased the PI3K/Akt pathway and phosphoERK protein levels leading to reduced activation of the RAF/RAS/MEK/ER pathway (52).

\section{Depsipeptides}

Depsipeptides (FK228) are bicyclic peptides mainly produced by Chromobacterium violaceum during fermentation (53). They have been mainly tested on ARO anaplastic thyroid cancer cells and there is evidence that they induced reexpression of NIS, TPO, Tg mRNAs and increased radioiodide uptake. The re-sensitization was not caused by TSH because its mRNA levels were low but probably by increasing NIS protein levels. Depsipeptides increased TTF1 levels but not the levels of Pax-8 and showed cytotoxicity only at higher doses, at around 3-10 ng/ml (54).

\begin{abstract}
AB1-13
AB1-13 are HDACIs that have conserved hydroxamic acid metal chelating groups that bind to the zinc moiety on HDACs and a conserved anisole hydrophobic cap. AB2, 3, 10 induce apoptosis and cell cycle arrest via increasing the levels of cyclin-dependent kinase inhibitor p21, p27 and decreasing the levels of cyclin D1. Moreover, they increased cleaved PARP and cleaved caspase 3 in $8505 \mathrm{C}$ cells. In Hth and 8505C cells, the AB2, 3, 10 increased mRNA levels of NIS. In Hth cells there was an increase in TSHR after the use of all members of the $\mathrm{AB}$ family but in $8505 \mathrm{C}$ cells, only $\mathrm{AB} 5$ and 10 had this effect. AB2, 3, 10 led to increased mRNA levels of PAX8 and TTF2 in Hth cells. AB3 was more selective for HDAC1, 2, 3 just like $\mathrm{AB} 2$, but was less potent than the latter (55).
\end{abstract}

\section{Panobinostat}

Panobinostat (LBH589), is a non-selective HDACI hydroxamic acid that has shown promising results in many experiments with anaplastic thyroid cancer cells. It led to increased apoptosis and cell cycle arrest not through Bcl2, Bcl-xl or Bax and Bak. It increased the number of cells at the $\mathrm{G}_{1}$ phase of the cell cycle. Furthermore, panobinostat increased p21 expression and reduced the levels of cyclin D1 in Cal-62 and 8505C cells (56). Importantly, treatment of BRAFV600+ ATC cells of an 83-yearold patient at stage IVC pT4aN1aM1 along with panobinostat and sorafenib, resulted in reduction of cell viability by nearly $100 \%$. It was shown that after $24 \mathrm{~h}$ of treatment with $10 \mathrm{nM}$ panobinostat the SLC5A5C (NIS) protein concentration was increased leading to up-regulation of radioiodine retention (57). The NIS concentration after $24 \mathrm{~h}$ of treatment with $10 \mathrm{nM}$ panobinostat increased but decreased if the treatment persisted for $48 \mathrm{~h}$ even though the RAI-U remained high (57).

Slightly different results were produced when panobinostat was used to treat ATC cells of a 42-year-old with a BRAFV600-tumor at IVB stage and pT4bN0M0 who survived 282 weeks after diagnosis. Sorafenib and panobinostat acted synergistically to increase NIS protein levels and RAI-U, and this increase was inversely correlated with the levels of hsa-let7g-5p mRNA, a tumor suppressor miRNA in thyroid cancer (57).

\section{Belinostat}

Belinostat (PXD101) acetylates H3 and induces the expression of p21 in both SW1736 and Cal62 anaplastic thyroid cancer cells. Furthermore, it decreased RAS-RAF, PI3K-mTOR, pERK, and Akt pathways. Treatment with 100 nM PXD101 resulted in 11-37\% apoptosis compared to the treatment with $50 \mathrm{nM}$ panobinostat that led to $43-68 \%$ apoptosis (58).

Furthermore, in combination with SNX5422, it led to higher levels of cytotoxicity, further suppression of the $\mathrm{PI} 3 \mathrm{~K} / \mathrm{Akt} / \mathrm{mTOR}$ pathway, inactivation of survivin and activation of DNA damage-related proteins by reducing the acetylation of $\mathrm{H} 3$ and $\mathrm{H} 4$ (36). When combined with NVPAUY922, it reduced the levels of phospho-ERK1, 2 and total and phosphor-Akt without affecting the hsp90 or hsp70 protein levels. However, this combination did not lead to the reduction of $\mathrm{H} 3, \mathrm{H} 4$ acetylation as seen with $\mathrm{SNX} 5422$, but to decreased levels of ATM and ATR proteins (59).

Belinostat showed promising results when used along with gemigliptin, a dipeptidyl peptidase-IV inhibitor in SW1736, 8505C anaplastic thyroid cancer cells. The combination synergistically augmented cell death and increased the number of apoptotic cells, the levels of $\mathrm{Bcl} 2$ protein, and cleaved poly ADP-ribose polymerase while it reduced the levels of XIAP and survivin proteins. Moreover, the levels of phospho-Akt and phospho-AMPK were elevated and cell migration was reduced (60).

\section{Triptolide}

Triptolide, a diterpenoid epoxide produced by the Tripterygium wilfordii, has shown antitumor activities in a broad range of solid tumors like pancreatic, breast and thyroid cancers. Treatment of anaplastic thyroid cancer with the combination of triptolide and BIIB021, a heat shock protein inhibitor, resulted in increased cytotoxicity, decreased cell 
viability, decreased levels of survivin protein and activation of DNA damage response. Moreover, they increased the levels of cleaved caspase 3, xIAP, cIAP and acetyl H4 (61).

\section{Conclusion}

One of the main reasons for the chemotherapy resistance observed in many cancers, including ATC, is the epigenetic modification of DNA leading to changes in gene expression. Histone acetylation/deacetylation is a significant mechanism that induces DNA methylation and chromatin remodeling, modifying gene transcription. The delicate balance between histone transacetylases and deacetylases is often disturbed in cancer, altering expression of tumor protooncogenes and tumor suppressor genes (62). The acetylation of histones is maintained by histone acetyltransferase and HDAC enzymes. However, HDAC enzymes are often over-functioning in cancer cells, indirectly leading to the acetylation of tumor protooncogenes and increased proliferation of cells (63-66). Therefore, HDACIs are drugs that specifically target cancer cells that have higher levels of acetylation, avoiding the complications of other not so targeted therapies like chemotherapy (67). Moreover, HDACIs have many more functions including invigoration of DNA repair mechanisms, induction of apoptosis and cell cycle arrest (68).

Even though there are many HDACIs under clinical trials, none is available for the treatment of ATC. The results of many in vitro experiments in cell lines are promising, with many HDACIs showing signs of cancer regression (69-71). These medications exert better results when used along with other anticancer drugs, but in some specific cases, monotherapy could also be considered.

Moreover, HDACIs may be even more valuable in ATC treatment, due to the failure of standard treatment used so far and its disappointing survival rate. The studies presented in this review justify further research in the field of HDACIs, in order to learn more about their functions and how they interact with other medications in order to be better utilized for the treatment of many cancers including ATC.

\section{Conflicts of Interest}

None of the Authors have any conflicts of interest to disclose regarding this study.

\section{Authors' Contributions}

Drafting of the manuscript: Spartalis E. and Athanasiadis D.I. Literature search and analysis: Athanasiadis D.I., Chrysikos D. Data extraction: Spartalis M. and Schizas D. Boutzios G performed quality assessment. Table drafting: Garmpis N. and Damaskos C. Manuscript editing: Paschou S.A. and Ioannidis A. Critical revision of the manuscript for important intellectual content: Tsourouflis G. and Dimitroulis D. Supervising professor: Nikiteas N.I.

\section{References}

1 Hundahl SA, Fleming ID, Fremgen AM and Menck HR: A National Cancer Data Base report on 53,856 cases of thyroid carcinoma treated in the U.S., 1985-1995. Cancer 83: 26382648, 1998. PMID: 9874472.

2 Kebebew E, Greenspan FS, Clark OH, Woeber KA and McMillan A: Anaplastic thyroid carcinoma: Treatment outcome and prognostic factors. Cancer 103: 1330-1335, 2005. PMID: 15739211, DOI: 10.1002/cncr.20936

3 Sherman EJ, Su YB, Lyall A, Schöder H, Fury MG, Ghossein RA, Haque S, Lisa D, Shaha AR, Tuttle RM and Pfister DG: Evaluation of romidepsin for clinical activity and radioactive iodine reuptake in radioactive iodine-refractory thyroid carcinoma. Thyroid 23: 593-599, 2013. PMID: 23186033, DOI: 10.1089/thy.2012.0393

4 Are C and Shaha AR: Anaplastic thyroid carcinoma: Biology, pathogenesis, prognostic factors, and treatment approaches. Ann Surg Oncol 13(4): 453-464, 2006. PMID: 16474910, DOI: 10.1245/ASO.2006.05.042

5 Connolly $\mathrm{C}$ and Glaholm J: Anaplastic thyroid cancer. Tips Tricks Endocr Surg 49: 143-147, 2014. DOI: https://doi.org/ 10.1007/978-1-4471-2146-6_17

6 Cheng TJ, Wang WC and Wang JD: Analysis of outpatient visits at a university hospital occupational and environmental clinic between 1987 and 1995. Chinese J Public Heal 18: 222-227, 1999.

7 Pierie JPEN, Muzikansky A, Gaz RD, Faquin WC and Ott MJ: The effect of surgery and radiotherapy on outcome of anaplastic thyroid carcinoma. Ann Surg Oncol 9(1): 57-64, 2002. PMID: 11833496.

8 Haigh PI, Ituarte PHG, Wu HS, Treseler PA, Posner MD, Quivey JM, Duh QY and Clark OH: Completely resected anaplastic thyroid carcinoma combined with adjuvant chemotherapy and irradiation is associated with prolonged survival. Cancer 91(12): 2335-2342, 2001. PMID: 11413523

9 Tennvall J, Lundell G, Wahlberg P, Bergenfelz A, Grimelius L, Åkerman M, Hjelm Skog AL and Wallin G: Anaplastic thyroid carcinoma: Three protocols combining doxorubicin, hyperfractionated radiotherapy and surgery. Br J Cancer 86(12): 1848-1853, 2002. PMID: 12085174, DOI: 10.1038/sj.bjc.6600361

10 McIver B, Hay ID, Giuffrida DF, Dvorak CE, Grant CS, Thompson GB, Van Heerden JA and Goellner JR: Anaplastic thyroid carcinoma: A 50-year experience at a single institution. Surgery 130(6): 1028-1034, 2001. PMID: 11742333, DOI: 10.1067/msy.2001.118266

11 Tan RK, Finley RK, Driscoll D, Bakamjian V, Hicks WL and Shedd DP: Anaplastic carcinoma of the thyroid: A 24-year experience. Head Neck 17(1): 41-47, 1995. PMID: 7883548.

12 Smallridge RC, Ain KB, Asa SL, Bible KC, Brierley JD, Burman KD, Kebebew E, Lee NY, Nikiforov YE, Rosenthal MS, Shah MH, Shaha AR and Tuttle for the American Thyroid Ass RM: American thyroid association guidelines for management of patients with anaplastic thyroid cancer. Thyroid 22(11): 11041139, 2012. PMID: 23130564, DOI: 10.1089/thy.2012.0302

13 Nagy L, Kao HY, Chakravarti D, Lin RJ, Hassig CA, Ayer DE, Schreiber SL and Evans RM: Nuclear receptor repression mediated by a complex containing SMRT, mSin3A, and histone deacetylase. Cell 89(3): 373-380, 1997. PMID: 9150137.

14 Hong L, Schroth GP, Matthews HR, Yau P and Bradbury EM: Studies of the DNA binding properties of histone $\mathrm{H} 4$ amino terminus. Thermal denaturation studies reveal that acetylation 
markedly reduces the binding constant of the H4 "tail" to DNA J Biol Chem 268(1): 305-314, 1993. PMID: 8416938.

15 Milano A, Chiofalo MG, Basile M, Salzano de Luna A, Pezzullo L and Caponigro F: New molecular targeted therapies in thyroid cancer. Anticancer Drugs 17: 869-879, 2006. PMID: 16940797, DOI: $10.1097 / 01 . c a d .0000224449 .16329 . c 5$

16 Gallinari P, Di Marco S, Jones P, Pallaoro M and Steinkühler C: HDACs, histone deacetylation and gene transcription: From molecular biology to cancer therapeutics. Cell Res 17(3): 195211, 2007. PMID: 17325692, DOI: 10.1038/sj.cr.7310149

17 Altucci L and Stunnenberg HG: Time for Epigenetics. Int J Biochem Cell Biol 41: 2-3, 2009. PMID: 18852065, DOI: 10.1016/j.biocel.2008.09.010

18 Giaginis C, Alexandrou P, Delladetsima I, Giannopoulou I, Patsouris E and Theocharis S: Clinical significance of histone deacetylase (HDAC)-1, HDAC-2, HDAC-4, and HDAC-6 expression in human malignant and benign thyroid lesions Tumor Biol 35: 61-71, 2014. PMID: 23873102, DOI: 10.1007/s13277-013-1007-5

19 Duvic $\mathrm{M}$ and $\mathrm{Vu}$ J: Vorinostat: a new oral histone deacetylase inhibitor approved for cutaneous T-cell lymphoma. Expert Opin Investig Drugs 16(7): 1111-1120 2007. PMID: 17594194, DOI: 10.1517/13543784.16.7.1111

20 Russo D, Damante G, Puxeddu E, Durante C and Filetti S: Epigenetics of thyroid cancer and novel therapeutic targets. J Mol Endocrinol 46(3): R73-81, 2011. PMID: 21325372 DOI: 10.1530/JME-10-0150

21 Marks PA and Xu WS: Histone deacetylase inhibitors: Potential in cancer therapy. J Cell Biochem 107(4): 600-608, 2009. PMID: 19459166, DOI: $10.1002 /$ jcb.22185

22 Luong QT, O'Kelly J, Braunstein GD, Hershman JM and Koeffler HP: Antitumor activity of suberoylanilide hydroxamic acid against thyroid cancer cell lines in vitro and in vivo. Clin Cancer Res 12(18): 5570-5577, 2006. PMID: 17000694, DOI: 10.1158/1078-0432.CCR-06-0367

23 Damaskos C, Garmpis N, Karatzas T, Nikolidakis L, Kostakis ID, Garmpi A, Karamaroudis S, Boutsikos G, Damaskou Z, Kostakis A and Kouraklis G: Histone deacetylase (HDAC) inhibitors: current evidence for therapeutic activities in pancreatic cancer. Anticancer Res 35(6): 3129-3135, 2015. PMID: 26026072

24 Woyach JA, Kloos RT, Ringel MD, Arbogast D, Collamore M, Zwiebel JA, Grever M, Villalona-Calero M and Shah MH: Lack of therapeutic effect of the histone deacetylase inhibitor vorinostat in patients with metastatic radioiodine-refractory thyroid carcinoma. J Clin Endocrinol Metab 94(1): 164-170, 2009. PMID: 18854394, DOI: 10.1210/jc.2008-1631

25 Brest $\mathrm{P}$, Lassalle S, Hofman V, Bordone O, Tanga VG, Bonnetaud C, Moreilhon C, Rios G, Santini J, Barbry P, Svanborg C, Mograbi B, Mari B and Hofman P: MiR-129-5p is required for histone deacetylase inhibitor-induced cell death in thyroid cancer cells. Endocr Relat Cancer 8(6): 711-719, 2011. PMID: 21946411, DOI: 10.1530/ERC-10-0257

26 Catalano MG, Pugliese M, Gallo M, Brignardello E, Milla P, Orlandi F, Limone PP, Arvat E, Boccuzzi G and Piovesan A: Valproic acid, a histone deacetylase inhibitor, in combination with paclitaxel for anaplastic thyroid cancer: Results of a multicenter randomized controlled phase II/III trial. Int J Endocrinol 2016: 2930414, 2016. PMID: 27766105, DOI: $10.1155 / 2016 / 2930414$
27 Venugopal B and Evans T: Developing histone deacetylase inhibitors as anti-cancer therapeutics. Curr Med Chem 18(11): 1658-1671, 2011. PMID: 21428881.

28 Chan D, Zheng Y, Tyner JW, Chng WJ, Chien WW, Gery S, Leong G, Braunstein GD and Koeffler HP: Belinostat and panobinostat (HDACI): In vitro and in vivo studies in thyroid cancer. J Cancer Res Clin Oncol 139: 1507-1514, 2013. PMID: 23824064, DOI: $10.1007 / \mathrm{s} 00432-013-1465-6$

29 Hou P, Bojdani E and Xing M: Induction of thyroid gene expression and radioiodine uptake in thyroid cancer cells by targeting major signaling pathways. J Clin Endocrinol Metab 95: 820-828, 2010. PMID: 20008023, DOI: 10.1210/jc.2009-1888

30 Akagi T, Luong QT, Gui D, Said J, Selektar J, Yung A, Bunce $\mathrm{CM}$, Braunstein GD and Koeffler HP: Induction of sodium iodide symporter gene and molecular characterisation of HNF3 $\beta /$ FoxA2, TTF-1 and C/EBP $\beta$ in thyroid carcinoma cells. Br J Cancer 99: 781-788, 2008. PMID: 18682709, DOI: 10.1038/sj.bjc.6604544

31 Allegri L, Mio C, Russo D, Filetti S and Baldan F: Effects of HuR downregulation on anaplastic thyroid cancer cells. Oncol Lett 15: 575-579, 2018. PMID: 29285201, DOI: 10.3892/ol.2017.7289

32 Wächter S, Damanakis A, Elxnat M, Roth S, Wunderlich A, Verburg F, Fellinger S, Bartsch D and Di Fazio P: Epigenetic modifications in thyroid cancer cells restore nis and radio-iodine uptake and promote cell death. J Clin Med 7(4): 61, 2018. PMID: 29561759, DOI: 10.3390/jcm7040061

33 Baldan F, Mio C, Allegri L, Puppin C, Russo D, Filetti S and Damante G: Synergy between HDAC and PARP inhibitors on proliferation of a human anaplastic thyroid cancer-derived cell line. Int J Endocrinol 2015: 978371, 2015. PMID: 25705225, DOI: $10.1155 / 2015 / 978371$

34 Clinckspoor I, Verlinden L, Overbergh L, Korch C, Bouillon R, Mathieu C, Verstuyf A and Decallonne B: 1,25-Dihydroxyvitamin D3 and a superagonistic analog in combination with paclitaxel or suberoylanilide hydroxamic acid have potent antiproliferative effects on anaplastic thyroid cancer. J Steroid Biochem Mol Biol 124: 1-9, 2011. PMID: 21182945, DOI: 10.1016/j.jsbmb.2010. 12.008

35 Borbone E, Berlingieri MT, De Bellis F, Nebbioso A, Chiappetta G, Mai A, Altucci L and Fusco A: Histone deacetylase inhibitors induce thyroid cancer-specific apoptosis through proteasomedependent inhibition of TRAIL degradation. Oncogene 29: 105116, 2010. PMID: 19802013, DOI: 10.1038/onc.2009.306

36 Kim SH, Kang JG, Kim CS, Ihm SH, Choi MG, Yoo HJ and Lee SJ: The heat shock protein 90 inhibitor SNX5422 has a synergistic activity with histone deacetylase inhibitors in induction of death of anaplastic thyroid carcinoma cells. Endocrine 51: 274-282, 2016. PMID: 26219406, DOI: 10.1007/ s12020-015-0706-7

37 Fortunati N, Catalano MG, Arena K, Brignardello E, Piovesan A and Boccuzzi G: Valproic acid induces the expression of the $\mathrm{Na}+$ /I- symporter and iodine uptake in poorly differentiated thyroid cancer cells. J Clin Endocrinol Metab 89: 1006-1009, 2004. PMID: 14764827, DOI: 10.1210/jc.2003-031407

38 Catalano MG, Fortunati N, Pugliese M, Marano F, Ortoleva L, Poli R, Asioli S, Bandino A, Palestini N, Grange C, Bussolati B and Boccuzzi G: Histone deacetylase inhibition modulates Ecadherin expression and suppresses migration and invasion of anaplastic thyroid cancer cells. J Clin Endocrinol Metab 97: 1150-1159, 2012. PMID: 22563106, DOI: 10.1210/jc.2011-2970 
39 Perona M, Thomasz L, Rossich L, Rodriguez C, Pisarev MA, Rosemblit C, Cremaschi GA, Dagrosa MA and Juvenal GJ: Radiosensitivity enhancement of human thyroid carcinoma cells by the inhibitors of histone deacetylase sodium butyrate and valproic acid. Mol Cell Endocrinol 478: 141-150, 2018. PMID: 30125607, DOI: 10.1016/j.mce.2018.08.007

40 Catalano MG, Pugliese M, Poli R, Bosco O, Bertieri R, Fortunati $\mathrm{N}$ and Boccuzzi G: Effects of the histone deacetylase inhibitor valproic acid on the sensitivity of anaplastic thyroid cancer cell lines to imatinib. Oncol Rep 21: 515-521, 2009. PMID: 19148530.

41 Catalano MG, Fortunati N, Pugliese M, Poli R, Bosco O, Mastrocola R, Aragno M and Boccuzzi G: Valproic acid, a histone deacetylase inhibitor, enhances sensitivity to doxorubicin in anaplastic thyroid cancer cells. J Endocrinol 191: 465-472, 2006. PMID: 17088416, DOI: 10.1677/joe.1.06970

42 Wang Y, Jin T, Dai X, Yan D and Peng Z: Histone deacetylase enzyme silencing using shRNAs enhances radiosensitivity of SW579 thyroid cancer cells. Mol Med Rep 14: 3509-3516, 2016. PMID: 27600599, DOI: 10.3892/mmr.2016.5711

43 Puppin C, D'Aurizio F, D'Elia AV, Cesaratto L, Tell G, Russo D, Filetti S, Ferretti E, Tosi E, Mattei T, Pianta A, Pellizzari L and Damante G: Effects of histone acetylation on NIS promoter and expression of thyroid-specific transcription factors. Endocrinology 146: 3967-3974, 2005. PMID: 15919754, DOI: 10.1210/en.2005-0128

44 Puppin C, Passon N, Franzoni A, Russo D and Damante G: Histone deacetylase inhibitors control the transcription and alternative splicing of prohibitin in thyroid tumor cells. Oncol Rep 25: 393-397, 2011. PMID: 21152868, DOI: 10.3892/ or.2010.1075

45 Greenberg VL, Williams JM, Cogswell JP, Mendenhall M and Zimmer SG: Histone deacetylase inhibitors promote apoptosis and differential cell cycle arrest in anaplastic thyroid cancer cells. Thyroid 11: 315-325, 2001. PMID: 11349829, DOI: $10.1089 / 10507250152039046$

46 Dong X, Korch C and Meinkoth JL: Histone deacetylase inhibitors upregulate Rap1GAP and inhibit Rap activity in thyroid tumor cells. Endocr Relat Cancer 18: 301-310, 2011. PMID: 21367844, DOI: 10.1530/ERC-10-0320

47 Lee YS, Kim SM, Kim BW, Chang HJ, Kim SY, Park CS, Park $\mathrm{KC}$ and Chang HS: Anti-cancer effects of HNHA and lenvatinib by the suppression of EMT-mediated drug resistance in cancer stem cells. Neoplasia (United States) 20: 197-206, 2018. PMID: 29331886, DOI: 10.1016/j.neo.2017.12.003

48 Park KC, Kim SM, Jeon JY, Kim BW, Kim HK, Chang HJ, Lee YS, Kim SY, Choi SH, Park CS and Chang HS: Synergistic activity of N-hydroxy-7-(2-naphthylthio) heptanomide and sorafenib against cancer stem cells, anaplastic thyroid cancer. neoplasia (United States) 19: 145-153, 2017. PMID: 28142087, DOI: 10.1016/j.neo.2016.12.005

49 Kim SM, Park KC, Jeon JY, Kim BW, Kim HK, Chang HJ, Choi SH, Park CS and Chang HS: Potential anti-cancer effect of Nhydroxy-7-(2-naphthylthio) heptanomide (HNHA), a novel histone deacetylase inhibitor, for the treatment of thyroid cancer. BMC Cancer 15: 1-11, 2015. PMID: 26698299, DOI: 10.1186/ s12885-015-1982-6

50 Petruzzella E, Sirota R, Solazzo I, Gandin V and Gibson D: Triple action Pt(iv) derivatives of cisplatin: A new class of potent anticancer agents that overcome resistance. Chem Sci 9: 42994307, 2018. PMID: 29780561, DOI: 10.1039/c8sc00428e
51 Zhang L, Boufraqech M, Lake R and Kebebew E: Carfilzomib potentiates CUDC-101-induced apoptosis in anaplastic thyroid cancer. Oncotarget 7(13): 16517-16528, 2016. PMID: 26934320, DOI: 10.18632 /oncotarget.7760

52 Kotian S, Zhang L, Boufraqech M, Gaskins K, Gara SK, Quezado M, Nilubol N and Kebebew E: Dual inhibition of HDAC and tyrosine kinase signaling pathways with CUDC-907 inhibits thyroid cancer growth and metastases. Clin Cancer Res 23: 5044-5054, 2017. PMID: 28600475, DOI: 10.1158/10780432.CCR-17-1043

53 Mitsiades CS, Poulaki V, McMullan C, Negri J, Fanourakis G, Goudopoulou A, Richon VM, Marks PA and Mitsiades N: Novel histone deacetylase inhibitors in thetreatment of thyroid cancer. Clin Cancer Res 11(10): 3958-3965, 2005. PMID: 15897598, DOI: 10.1158/1078-0432.CCR-03-0776

54 Furuya F, Shimura H, Suzuki H, Taki K, Ohta K, Haraguchi K, Onaya $\mathrm{T}$, Endo $\mathrm{T}$ and Kobayashi $\mathrm{T}$ : Histone deacetylase inhibitors restore radioiodide uptake and retention in poorly differentiated and anaplastic thyroid cancer cells by expression of the sodium/iodide symporter thyroperoxidase and thyroglobulin. Endocrinology 145: 2865-2875, 2004. PMID: 14976143, DOI: 10.1210/en.2003-1258

55 Jang S, Yu XM, Odorico S, Clark M, Jaskula-Sztul R, Schienebeck CM, Kupcho KR, Harrison AD, WinstonMcpherson GN, Tang W and Chen H: Novel analogs targeting histone deacetylase suppress aggressive thyroid cancer cell growth and induce re-differentiation. Cancer Gene Ther 22: 410416, 2015. PMID: 26251030, DOI: 10.1038/cgt.2015.37

56 Catalano MG, Pugliese M, Gargantini E, Grange C, Bussolati B, Asioli S, Bosco O, Poli R, Compagnone A, Bandino A, Mainini F, Fortunati N and Boccuzzi G: Cytotoxic activity of the histone deacetylase inhibitor panobinostat (LBH589) in anaplastic thyroid cancer in vitro and in vivo. Int J Cancer 130: 694-704, 2012. PMID: 21400508, DOI: 10.1002/ijc.26057

57 Wächter S, Wunderlich A, Roth S, Mintziras I, Maurer E, Hoffmann S, Verburg FA, Fellinger SA, Holzer K, Bartsch DK and Di Fazio P: Individualised multimodal treatment strategies for anaplastic and poorly differentiated thyroid cancer. J Clin Med 7(5): 115, 2018. PMID: 29762469, DOI: 10.3390/jcm7050115

58 Chan D, Zheng Y, Tyner JW, Chng WJ, Chien WW, Gery S, Leong G, Braunstein GD and Koeffler HP: Belinostat and panobinostat (HDACI): In vitro and in vivo studies in thyroid cancer. J Cancer Res Clin Oncol 139(9): 1507-1514, 2013. PMID: 23824064, DOI: 10.1007/s00432-013-1465-6

59 Kim SH, Kang JG, Kim CS, Ihm SH, Choi MG, Yoo HJ and Lee SJ: Novel heat shock protein 90 inhibitor NVP-AUY922 synergizes with the histone deacetylase inhibitor PXD101 in induction of death of anaplastic thyroid carcinoma cells. J Clin Endocrinol Metab 100: E253-E261, 2015. PMID: 25389633, DOI: $10.1210 /$ jc.2014-3101

60 Kim SH, Kang JG, Kim CS, Ihm SH, Choi MG, Yoo HJ and Lee SJ: Gemigliptin, a novel dipeptidyl peptidase-IV inhibitor, exerts a synergistic cytotoxicity with the histone deacetylase inhibitor PXD101 in thyroid carcinoma cells. J Endocrinol Invest 41(6): 677-689. 2018. PMID: 29147952, DOI: 10.1007/s40618-0170792-x

61 Kim SH, Kang JG, Kim CS, Ihm SH, Choi MG, Yoo HJ and Lee SJ: Synergistic cytotoxicity of BIIB021 with triptolide through suppression of $\mathrm{PI} 3 \mathrm{~K} / \mathrm{Akt} / \mathrm{mTOR}$ and NF- $x \mathrm{~B}$ signal pathways in thyroid carcinoma cells. Biomed Pharmacother 83: 22-32, 2016. 
$62 \mathrm{Kim}$ HJ and Bae SC: Histone deacetylase inhibitors: Molecular mechanisms of action and clinical trials as anti-cancer drugs. Am J Transl Res 83: 22-32 2011. PMID: 27470546, DOI: 10.1016/ j.biopha.2016.06.014

63 Tsilimigras DI, Ntanasis-Stathopoulos I, Moris D, Spartalis E and Pawlik TM: Histone deacetylase inhibitors in hepatocellular carcinoma: A therapeutic perspective. Surg Oncol 27(4): 611618, 2018. PMID: 30449480, DOI: 10.1016/j.suronc.2018. 07.015

64 Schizas D, Mastoraki A, Naar L, Spartalis E, Tsilimigras DI, Karachaliou GS, Bagias G, Moris D: Concept of histone deacetylases in cancer: Reflections on esophageal carcinogenesis and treatment. World J Gastroenterol 24(41): 4635-4642, 2018 PMID: 30416311, DOI: 10.3748/wjg.v24.i41.4635.

65 Garmpi A, Garmpis N, Damaskos C, Valsami S, Spartalis E, Lavaris A, Patelis N, Margonis GA, Apostolou KG, Spartalis M, Andreatos N, Diamantis E, Tsivelekas K, Moschos MM, Nonni A, Tsourouflis G, Markatos K, Antoniou EA, Kontzoglou K, Nikiteas $\mathrm{N}$ and Dimitroulis D: Histone deacetylase inhibitors as a new anticancer option: How far can we go with expectations? delivery systems. J BUON 23(4): 846-861, 2018. PMID: 30358185 .

66 Garmpis N, Damaskos C, Garmpi A, Spartalis E, Kalampokas E, Kalampokas T, Margonis GA, Schizas D, Andreatos N, Angelou A, Lavaris A, Athanasiou A, Apostolou KG, Spartalis M, Damaskou Z, Daskalopoulou A, Diamantis E, Tsivelekas K, Alavanos A, Valsami S, Moschos MM, Sampani A, Nonni A, Antoniou EA, Mantas D, Tsourouflis G, Markatos K, Kontzoglou K, Perrea D, Nikiteas N, Kostakis A and Dimitroulis D: Targeting histone deacetylases in endometrial cancer: a paradigm-shifting therapeutic strategy? Eur Rev Med Pharmacol Sci 22(4): 950-960, 2018. PMID: 29509243, DOI: 10.26355/eurrev_201802_14376

67 Damaskos C, Tomos I, Garmpis N, Karakatsani A, Dimitroulis D, Garmpi A, Spartalis E, Kampolis CF, Tsagkari E, Loukeri AA, Margonis GA, Spartalis M, Andreatos N, Schizas D, Kokkineli S, Antoniou EA, Nonni A, Tsourouflis G, Markatos K, Kontzoglou K, Kostakis A and Tomos P: Histone deacetylase inhibitors as a novel targeted therapy against non-small cell lung cancer: where are we now and what should we expect? Anticancer Res 38(1): 37-43, 2018. PMID: 29277754, DOI: 10.21873/anticanres.12189
68 Garmpis N, Damaskos C, Garmpi A, Dimitroulis D, Spartalis E, Margonis GA, Schizas D, Deskou I, Doula C, Magkouti E, Andreatos N, Antoniou EA, Nonni A, Kontzoglou K and Mantas D: Targeting histone deacetylases in malignant melanoma: a future therapeutic agent or just great expectations? Anticancer Res 37(10): 5355-5362, 2017. PMID: 28982843, DOI: 10.21873/ anticanres. 11961

69 Garmpis N, Damaskos C, Garmpi A, Kalampokas E, Kalampokas T, Spartalis E, Daskalopoulou A, Valsami S, Kontos M, Nonni A, Kontzoglou K, Perrea D, Nikiteas $\mathrm{N}$ and Dimitroulis D: Histone deacetylases as new therapeutic targets in triple-negative breast cancer: progress and promises. Cancer Genomics Proteomics 14(5): 299-313, 2017. PMID: 28870998, DOI: $10.21873 / \mathrm{cgp} .20041$

70 Damaskos C, Garmpis N, Valsami S, Kontos M, Spartalis E, Kalampokas T, Kalampokas E, Athanasiou A, Moris D, Daskalopoulou A, Davakis S, Tsourouflis G, Kontzoglou K, Perrea D, Nikiteas N and Dimitroulis D: Histone deacetylase inhibitors: an attractive therapeutic strategy against breast cancer. Anticancer Res 37(1): 35-46, 2017. PMID: 28011471, DOI: 10.21873 /anticanres.11286

71 Damaskos C, Garmpis N, Valsami S, Spartalis E, Antoniou EA, Tomos P, Karamaroudis S, Zoumpou T, Pergialiotis V, Stergios K, Michaelides C, Kontzoglou K, Perrea D, Nikiteas N and Dimitroulis D: Histone deacetylase inhibitors: a novel therapeutic weapon against medullary thyroid cancer? Anticancer Res 36(10): 5019-5024, 2016. PMID: 27798860, DOI: 10.21873 /anticanres. 11070
Received January 25, 2019

Revised February 15, 2019

Accepted February 18, 2019 